\title{
Anterior ischaemic optic neuropathy
}

TO THE EDITOR British Yournal of Ophthalmology, SIR, I should like to thank Dr Sohan Singh Hayreh for calling attention to my annual review of neuro-ophthalmology (Lessell, 1974). In it the reader will find that I devoted a paragraph to several of Dr Hayreh's many excellent studies on anterior ischaemic optic neuropathy (AION) (Hayreh, 1974). Dr Hayreh cavils at my comment that there are obvious differences between spontaneous human AION and the AION that is produced in monkeys. Regardless of whether or not I was correct in my observation, these differences are only of secondary importance and do not detract from Dr Hayreh's convincing demonstration of the central role of the posterior ciliary arteries in the pathogenesis of AION. Dr Hayreh also accuses me of making a misleading and dangerous statement concerning the differential diagnosis of optic atrophy. However, I neither stated nor implied that metastatic tumour was a more common cause of optic atrophy than AION. What I wanted to convey was that

\section{Notes}

\section{Pan-Hellenic Ophthalmological Congress}

\section{Thessaloniki, 28 to 30 May 1976}

The ninth congress will be held in Thessaloniki, Greece. The subjects will be: Steroids and antibiotics in ophthalmology, Surgery of the lids, and Iatrogenic eye diseases.

\section{Canadian Ophthalmological Society}

\section{Quebec City, 6 to 9 June 1976}

The 39th annual meeting will be held at the Quebec Hilton Hotel under the theme 'Medical aspects of the retina'.

Dr Pierre Almaric of Albi, France, and Dr H. Mackenzic Freeman of the Retina Association in Boston will be this year's special guests; they will present papers to the various scientific sessions.

\section{The Eldridge-Green Lecture}

\section{London, 10 Fune 1976}

The Eldridge-Green Lecture entitled 'The biological significance of optical illusions' will be delivered under the auspices of the Royal College of Surgeons of England if you observe a patient throughout the course of his illness (including the acute phase) and at no time is optic disc oedema observed, you should be dubious of the diagnosis of AION.

Dr Hayreh and I probably hold very similar views on AION. Perhaps this letter will make that apparent. In any case, a reading of my review (Lessell, 1974) and the relevant papers of Dr Hayreh (Hayreh, 1974) should show that there is no foundation for serious controversy. Yours faithfully, SIMMONS LESSELL.

Boston University School of Medicine,

8o East Concord Street,

Boston,

Massachusetts, USA

\section{References}

HAYREH, s. S. (1974) Brit. F. Ophthal., 58, 955, 964, $98 \mathrm{I}$

Lessel., s. (1974) Arch. Ophthal., 91, I 66
There will be simultaneous translations in English and French.

For further information write to the Ophthalmological Society of North Greece, PO Box 497, 'Thessaloniki, Greece.

Two half days will be devoted to discussions on the prevention of blindness, cataract, uvea, and surgical aspects of the retina. Research sessions will be held on Sunday, June 6 , in the afternoon.

For further information write to the Canadian Ophthalmological Socicty, PO Box 8650, Ottawa, Ontario, Ki $\mathrm{G}_{\mathrm{O}} \mathrm{OG}$, Canada. by Professor R. A. Weale at $3 \mathrm{pm}$, at the Institute of Ophthalmology, Cayton Street (adjacent to Moorfields Hospital, City Road), London. Tickets are not required. 